\title{
Modeling The Effects Of Socio- Demographic, Psychographic And Relationship Characteristics On Share Of Wallet For Financial Services
}

Raymond T. Kong, Ipsos, Canada

Manfred F. Maute, York University, Canada

\begin{abstract}
Customer Loyalty is frequently conceptualized as customer retention even though polygamous loyalty to multiple products/brands is commonplace and customers are unlikely to shift all of their purchases to another supplier following dissatisfaction. In this study, loyalty is operationalized as share of wallet (SOW) and modeled in relation to socio-demographic, psychographic and relationship predictors. Results indicate that chequing account SOW was negatively skewed and leptokurtic with a mean of $83.3 \%$. In contrast, mean credit card SOW was 59.5\% and the distribution was negatively skewed and platykurtic. Relationship length, depth and satisfaction, and financial attitudes, values and lifestyles, but not consumer socio-demographics, emerged as key predictors of share of wallet.
\end{abstract}

Keywords: customer equity; loyalty; customer satisfaction; financial services; share of wallet

\section{INTRODUCTION}

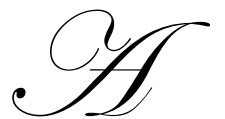

$s$ the central construct in the relational exchange paradigm, loyalty has been modeled as an outcome of customer evaluations as well as an antecedent of customer behaviors and financial outcomes (Bolton, Lemon \& Verhoef 2004). The ongoing interest in loyalty is one manifestation of the attention that marketers and researchers continue to focus on understanding how relationships are cultivated and managed among the firm's stock of current and potential customers (Blattburg \& Deighton 1996). While customers were seen to be either completely or not at all loyal, loyalty was conceptualized as customer retention, and lifetime customer value was believed to be primarily a function of relationship tenure (Reinartz \& Kumar 2000). However, as polygamous loyalty to multiple products/brands has become commonplace (Uncles, Dowling \& Hammond 2003) and customers exhibit greater reluctance to shift all of their purchases to other suppliers following dissatisfaction (Perkin-Munn et al. 2005), research has begun to represent loyalty as share of wallet (SOW), the proportion of a customer's spending in a product category assigned to the brand/product of a single supplier (see Cooil et al. 2007).

Considerable research has been devoted to customer retention, but our understanding of share of wallet and the factors that affect this representation of loyalty is far from complete (Rust, Lemon \& Zeithaml 2004). Using data from a large financial services panel that is more complete and reliable than single source or declarative survey data, we operationalize customer loyalty as share of wallet, contrast SOW for chequing accounts and credit cards, and respond to the inconclusive research on the factors that affect this contemporary representation of loyalty by modeling SOW in relation to a comprehensive set of socio-demographic, psychographic and relationship predictors.

\section{BACKGROUND}

Relational exchange represents a new approach to marketing that is customer-focused and relationship rather than transaction-oriented. The key premise of the relational exchange paradigm is that customers are the 
firm's most valuable strategic asset and the management of relationships with those customers is the ultimate source of long-run profitability. In building a proprietary learning partnership, marketers come to understand each customer's needs, discover how to customize their product/service offerings to deliver value and defeat competition, and insulate their business from price competition and commoditization (Peppers \& Rogers, 2004).

Customer loyalty, "a deeply held commitment to re-buy or re-patronize a preferred product/service in the future" (Oliver 1999, p. 34), is the central construct in the relational exchange paradigm, appearing in theoretical models as both an outcome of evaluations like service quality and satisfaction and an antecedent of purchase behaviors and customer value (Bolton, Lemon \& Verhoef 2004). Whereas the initial focus on loyalty arose from practical insights about the profitability of long tenure customers (Reicheld 1996; Zeithaml 2000), subsequent research has demonstrated that long as well as deep relationships enhance customer value (Hogan, Lemon \& Rust 2002). Customer profitability is now acknowledged to arise from both tenure and value, reflecting the effect of loyalty on product usage, price sensitivity, operating costs, cross-buying and word-of-mouth over time (Verhoef 2003; Meyer-Waarden 2007).

Research that provides prescriptions for managing the customer asset are plentiful. The customer asset management of services (CUSAM) model is a "granular, theory-based" framework that links marketing actions to customer retention and profit (Bolton, Lemon \& Verhoef 2003, pg. 19). According to the model, marketing instruments (i.e., loyalty programs, distribution channels, marketing communications, etc.) influence lifetime customer value through purchase behaviors such as service usage, relationship duration and cross buying. Verhoef's partial test of the CUSAMS model (2003) finds that direct mail and loyalty programs enhance different aspects of loyalty. Although the effect accounts for only one tenth of the explained variation in customer loyalty, Verhoef argues that the effect of marketing instruments on loyalty can tip the competitive balance in "near stationary" markets characterized by limited differentiation and intense competition.

In taking a broader view of the antecedents of loyalty than is implied by the CUSAM model, manageriallyoriented frameworks specify evaluations such as service quality and satisfaction as antecedents of loyalty and customer value. Research on the service profit chain shows that service quality is related to re-purchase intentions (Zeithaml, Berry \& Parasuraman 1996), customer retention (Bolton 1998) and profits (Anderson, Fornell \& Lehmann 1994). Satisfaction, the affective state resulting from the appraisal of a customer's interactions with a service provider over time (see Anderson \& Narus 2003), is the most widely researched antecedent of loyalty in studies that focus on actual customer behavior, as opposed to attitudes (i.e., affective commitment) or behavioral intentions (Bolton, 1998; Mittal \& Kamakura, 2001; Rust, Zahorik \& Keiningham, 1995). Anderson and Mittal (2000) use the term "satisfaction-profit chain" to describe how the optimization of attribute-level performance increases satisfaction, which in turn leads to greater loyalty and profits.

Despite the amount of research conducted on the satisfaction-loyalty relationship, results are far from conclusive. A meta analysis by Szymanski and Henard (2001) finds that satisfaction has a positive effect on selfreported customer loyalty, while Hallowell (1996) observes that satisfaction accounts for thirty-seven percent of the variation in retail banking loyalty, the service context of the present study. Bloemer, Ruyter and Peelers (1998) report that satisfaction not only increases loyalty, but also mediates the effect of service quality on loyalty. Verhoef (2003), however, observes no effect of satisfaction on loyalty and other researchers attribute weak or inconsistent results to a variety of factors including a relationship that is dynamic rather than static (Mittal, Kumar \& Tsiros 1999), non-linear (Anderson \& Mittal 2000), asymmetric (Mittal et al. 1998) and moderated by various product, industry and consumer characteristics (Walsh, Evanschintzky \& Wunderlich 2007).

Notwithstanding the ambiguity apparent in much of the literature on the satisfaction-loyalty relationship, disagreement about the conceptualization of the loyalty construct remains the most important obstacle to research progress. In many studies, loyalty continues to be conceptualized as customer retention even though polygamous loyalty to several products/brands is increasingly common (see Rust, Lemon \& Zeithaml, 2004; Uncles, Dowling \& Hammond, 2003) and customers are more likely to shift a portion, rather than all of their purchases to a competing product/supplier following dissatisfaction (Perkins-Munn et al., 2005). Keiningham, Perkins-Munn and Evans (2003) report that marketing managers increasingly view share of wallet as a more accurate reflection of loyalty than repurchase, while Coyles and Grokey (2002) conclude that firms that manage both share of wallet and customer 
retention can increase profits by an order of magnitude greater than by focusing on retention alone.

Conceptualizing loyalty as share of wallet, Cooil et al. (2007) find a positive relationship between changes in satisfaction and SOW, with income and relationship length emerging as negative moderators of the satisfactionSOW relationship. Satisfaction, however, explains only "modest" variation in SOW in Magi's study of grocery retailing (2003) and the effect is moderated by some consumer psychographics (i.e., preference for social interaction), but not socio-demographic characteristics like age and gender. Other studies that rely on increasingly sophisticated research methodologies and data examine the effect of loyalty programs on SOW. Magi (2003), for example, finds mixed support for the positive effect of loyalty cards on SOW but notes that for holders of multiple loyalty cards, the effects of any one loyalty program are cancelled out. Using single source panel data to investigate share of wallet for grocery stores, Meyer-Warden (2006) observes an increase in lifetime duration and share of expenditure among loyalty card holders. Interestingly, lifetime duration decreases among customers who hold multiple loyalty card memberships for geographically close retailers.

The present study addresses the limitations of past research by operationalizing loyalty as share of wallet and utilizing data from a large, ongoing financial services panel that is more complete and reliable than single source or declarative survey data to compare and contrast SOW for chequing accounts and credits. We then model this representation of customer loyalty in relation to a comprehensive set of predictors that include not only customer satisfaction and socio-demographic characteristics, but also psychographic and relationship variables.

\section{METHODS}

Data was gathered by mail diary from an ongoing panel of 12,000 nationally representative Canadian households. Of the 5,945 households for which psychographic (VALS) data was available, 1,603 identified a large Canadian bank as their primary financial institution. In contrast with Cooil et al. (2007) who estimate share of wallet for a basket of "money-in" transactions (e.g., chequing, savings, investments), we compute SOW separately for chequing accounts and credit cards, a perspective that facilitates comparisons of loyalty for different financial services and yields results that are managerially actionable at the "product" level.

Using this approach, credit card SOW is measured as the proportion of charges against a major credit card issued by the primary bank relative to the total of all credit card charges in the preceding month for 803 households who made a recent credit card purchase. Chequing SOW is measured as the proportion of the average monthly balance held in chequing accounts with the primary financial institution relative to the average total balances for all accounts for 772 households who held at least one chequing account with their primary financial institution. Satisfaction with up to three financial institutions is measured on a four-point semantic differential scale $(1=$ 'extremely dissatisfied' - 4= 'extremely satisfied'). A twenty-four item, ten-point, Likert-type agreement scale (1='strongly disagree' $-10=$ 'strongly agree') is used to capture financial values, attitudes and lifestyles (VALS). Relationship tenure is measured as the number of consecutive years that the household has maintained a relationship with a financial institution, while a measure of relationship depth is obtained by counting the number of unique financial service products purchased from the primary institution.

\section{RESULTS}

Figure 1 presents the SOW distributions for chequing and credit cards graphically. The mean chequing account balance for the primary financial institution was $\$ 9,641$ (S.D.: $\$ 20,658$ ) with a range of $\$ 0$ to $\$ 317,500$. Mean chequing SOW was $83.3 \%$ (S.D.: 0.31) and the distribution was negatively skewed (skewness: -1.70 ) and leptokurtic (kurtosis: 1.42). Mean credit card charges for the most recent month were \$1,247 (S.D.: \$ 2,148) with a range of $\$ 3$ to $\$ 20,000$. Mean credit card SOW was $59.5 \%$ (S.D.: 0.41 ) and the distribution was negatively skewed (skewness: -0.396) and platykurtic (kurtosis: -1.57$)$. 
Figure 1: Frequency Distributions of Credit Card and Chequing Share of Wallet (by Percent)
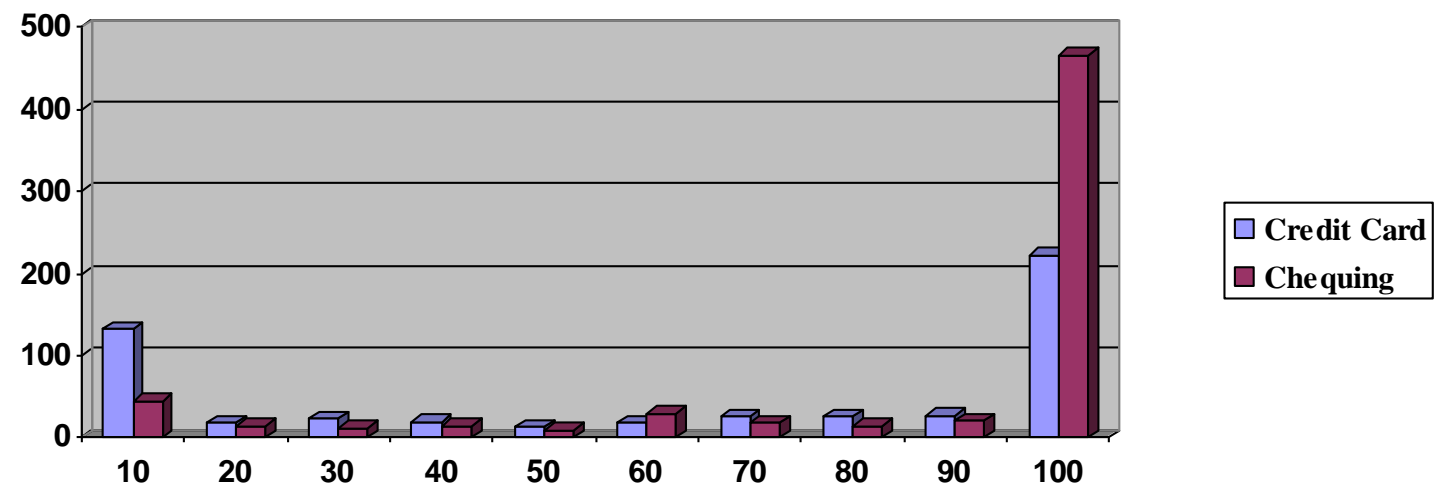

Mean tenure with the primary financial institution was 15.4 years, with two thirds of households reporting a banking relationship of 20 or more years. Mean satisfaction with the primary institution was 3.52 (on a four-point scale) with almost six in ten households declaring themselves 'extremely satisfied'. On average, 4.16 financial products (range 0-8) were purchased from the primary institution. Slightly more than one third of households reported a long and highly satisfactory banking relationship with a second financial institution.

Table 1 presents the results of an exploratory factor analysis of a multi-item scale that measures financial values, attitudes and life styles. Since Bartlett's test of sphericity $\left(\chi^{2}{ }_{61}=234.33, p<.000\right)$ and the KMO measure of sampling adequacy $(\mathrm{KMO}=0.62)$ indicated that factor analysis was appropriate, five factors accounting for $50 \%$ of the total variance were extracted using the eigenvalue criterion. Interpretation of the pattern matrix identified the following factors: F1: value independent, objective financial advice; F2: comfortable with current financial situation/prospects for retirement; F3: not money savvy/troubled by debt; F4: willing to take risks/borrow against home to invest; and F5: actively search for new offers/ negotiate best deal.

Table 1: Factor Structure of Financial Values, Attitudes and Life Styles Measure

\begin{tabular}{|c|c|c|c|c|c|}
\hline & Factor 1 & Factor 2 & Factor 3 & Factor 4 & Factor 5 \\
\hline L8Q14 & .615 & & & & .110 \\
\hline L8Q24 & .321 & & & & .187 \\
\hline L8Q2 & .303 & & & .199 & \\
\hline L8Q9 & & -.736 & & & \\
\hline L8Q8 & & -.637 & & & \\
\hline L8Q17 & & -.204 & -.108 & .183 & .187 \\
\hline L8Q7 & .136 & -.169 & -.133 & .133 & .102 \\
\hline L8Q12 & & & -.645 & & \\
\hline L8Q13 & .194 & & -.526 & & \\
\hline L8Q18 & & & -.378 & & .120 \\
\hline L8Q11 & & .198 & -.348 & .249 & \\
\hline L8Q5 & & & & .565 & \\
\hline L8Q10 & & -.115 & & .371 & .106 \\
\hline L8Q4 & .120 & & & .349 & \\
\hline L8Q20 & & & & & .592 \\
\hline L8Q19 & & & & & .492 \\
\hline L8Q22 & & & -.130 & & .329 \\
\hline
\end{tabular}

Credit card households were then clustered on SOW using a non-hierarchical, two step clustering procedure and a log-likelihood distance measure. The four cluster solution was chosen for further analysis based on cluster 
heterogeneity, the distribution of observations and interpretability. Table 2 summarizes the number of observations and mean credit card SOW for each of the four clusters. Broadly, these results provide support for the existence of four sizable clusters with the very low and very high SOW clusters accounting for most of the observations.

Table 2: Cluster Size and Credit Card Share of Wallet

\begin{tabular}{|c|c|c|}
\hline Cluster & Observations & Share of Wallet (\%) \\
\hline 1 & 142 & 2 \\
\hline 2 & 61 & 30 \\
\hline 3 & 77 & 66 \\
\hline 4 & 246 & 98 \\
\hline
\end{tabular}

Differences between clusters were then investigated with multiple discriminant analysis, using socioeconomic characteristics, VALS factor scores and relationship variables as predictors of cluster membership. All three discriminant functions were statistically significant at 0.10 . A jack-knife procedure used to cross-validate the discriminant solution yielded a hit rate of $49 \%$, about twice what would be expected by chance alone. Customer satisfaction, relationship variables and VALS, but not socio-demographic characteristics, emerged as key sources of discrimination for credit card SOW.

The first discriminant function (Wilk's $\lambda=0.653, \mathrm{p}<.000$ ) accounted for $54.7 \%$ of the total variance and was dominated by relationship variables including length of relationship with the primary and secondary financial institution and relationship depth. Satisfaction with the primary financial institution and several VALS factors including F1 (value independent financial advice), F2 (comfort level with current financial situation) and F4 (risktaking) appeared as predictors in the second discriminant function (Wilk's $\lambda=0.819, \underline{p}<.022$ ) that accounted for $25.4 \%$ of the total variance. VALS factors F3 (not money savvy/troubled by debt) and F5 (actively search for new offers/negotiate best deal) loaded on the third function (Wilk's $\lambda=0.916, \underline{p}<.080$ ). Neither age of the household head, income, nor household size were related to credit card SOW. Table 3 presents the standardized canonical discriminant function coefficients for the three functions.

Table 3: Standardized Discriminant Function Coefficients

\begin{tabular}{|l|c|c|c|}
\hline & Function 1 & Function 2 & Function 3 \\
\hline RelationshipLength_1 & -.339 & .240 & .237 \\
\hline Satisfaction_1 & .366 & .617 & .099 \\
\hline RelationshipLength_2 & .359 & -.134 & -.118 \\
\hline Satisfaction_2 & .022 & -.147 & .115 \\
\hline Relationship Depth & .743 & -.205 & .259 \\
\hline VALS Factor_1 & -.101 & .435 & .355 \\
\hline VALS Factor_2 & .118 & -.638 & .568 \\
\hline VALS Factor_3 & .309 & .077 & -.387 \\
\hline VALS Factor_4 & -.312 & .433 & .046 \\
\hline VALS Factor_5 & -.059 & .311 & .368 \\
\hline
\end{tabular}

\section{DISCUSSION AND CONCLUSIONS}

Three limitations affect the interpretation of these results. First, the study is confined to two financial products, a single financial institution and one national banking market and findings may not be generalizable to other products, customers and markets. Second, non-linear and asymmetric effects are not incorporated in the SOW model, and while customer characteristics are modeled, other contextual factors are not. Third, since cluster analysis is acknowledged to be atheoretical and non-inferential (Hair et al., 2006), discriminant solutions with fewer or greater numbers of clusters could produce different results. Despite these limitations, results highlight the statistical properties of SOW for two different financial service products, identify interesting similarities and differences in chequing account and credit card SOW and provide insights into the how customer satisfaction, financial values and life styles, and relationship length and depth are related to SOW. 
Chequing and credit card SOW for a financial institution that is a market leader and among the top 20 worldwide banks in market capitalization are likely to represent high water marks for Canadian banking. Interestingly, mean credit card SOW of 59.5\% was similar to the $62 \%$ SOW reported by Magi (2003), despite the obvious differences between banking and grocery retailing. High SOW is not unexpected for an anchor 'product' like chequing where customers are less likely to patronize multiple banks and switching costs are high. That six of out ten dollars of credit card spending could be captured speaks to the effects that partnering a powerful credit card brand with a leading financial institution can have on loyalty, low switching costs and the presence of more than thirty competing card products in the market notwithstanding.

Despite mean values that differ, chequing and credit card SOW exhibited similar U shaped distributions with largely unremarkable differences between $10 \%$ and $90 \%$. The higher mean SOW for chequing reflects a distribution that is more peaked and less negatively skewed, with only one-third as many low SOW customers $(7.1 \%$ versus $25.3 \% \leq .10 \mathrm{SOW})$ and twice as many customers with very high SOW $(69.5 \%$ versus $34 \%>.90 \mathrm{SOW})$ as credit cards. Since chequing SOW is already at a high level, cross-selling other products to chequing customers may generate more profit than attempts to increase SOW. The scope for cultivating loyalty among credit card customers is somewhat greater. Shifting low and moderate SOW customers to higher levels of loyalty in combination with winding down relationships with unpromising low SOW customers offer the potential to increase not only loyalty, but also profit.

The characterization of retail banking as a subscription market in which loyal customers allocate most of their business to one or two service providers for long periods of time (see Garland 2004) appears to be an accurate reflection of the long, deep and generally very satisfying relationships that customers experienced with their primary financial institution. That mean satisfaction was rated 3.92/4.00 and almost six in ten households rated themselves as 'extremely satisfied' with their primary bank provides evidence that customer satisfaction is the foundation for long-term loyalty among most of the customers in this study. High levels of performance on the service quality dimensions of reliability, assurance, tangibility, empathy and responsiveness will ensure continuing satisfaction and loyalty among these customers. But, annual rates of customer defection estimated at 5-15\% imply that even among market leaders, not all retail banking customers will be satisfied (see Trubik \& Smith 2000). Since the loyalty of dissatisfied customers is ensured more so by "inertia" than satisfaction (Garland, 2002), prudent management of the customer asset implies the need to devote effort to remedying the dissatisfaction of inert customers, rather than relying solely on switching costs to ensure their loyalty.

Results suggest that relationship length and depth are powerful discriminators of credit card SOW. Interestingly, post-hoc contrasts indicate that longer and deeper relationships were consistently associated with higher levels of SOW in much the same manner as satisfaction. The present study does not resolve the question of whether deeper banking relationships promote SOW, or higher SOW stimulates customers to deepen their relationships. To the extent that the former is true, lengthening and deepening banking relationships by providing customers with relational benefits like enhanced customer service, status and rewards and cross-selling could have the same effect on SOW as increases in satisfaction.

Financial values, attitudes and life styles were related to SOW, suggesting that psychographics like financial sophistication, risk tolerance and deal proneness, more so that socio-demographic characteristics like age income and household size, offer promising opportunities for segmenting and targeting credit card customers. Detailed analysis of cluster differences shows that very high SOW customers ascribed less value to independent financial advice and were less comfortable with their current financial situation than moderate/high SOW customers, but did not differ significantly on risk tolerance. Similarly, low/moderate SOW customers lacked financially sophistication, were troubled by debt and responded to deals more than very high SOW customers. Marketers can use this understanding of financial values, attitudes and lifestyles to identify less profitable (i.e., low SOW) customers, scale the level of marketing expenditures to match the profit potential of different market segments on the basis of a more relevant representation of loyalty than is implied by customer retention, and craft products and marketing communications that appeal directly to the needs of different loyalty segments.

Long and satisfactory banking relationships were not confined to the primary financial institution. Thirtyfive percent of households maintained a long (mean tenure: 15.7 years) and highly satisfactory relationship (mean 
satisfaction: 3.49/4.00) with a second financial institution. Post-hoc contrasts revealed that SOW at the primary bank was lower for customers with longer secondary banking relationships. Banking relationships persist for many reasons, out of habit, neglect, or to permit customers to take advantage of differences in product availability, service or value among financial institutions. Irrespective of the motivation for maintaining such a relationship, the implication is that customers can shift some or all of their business away from their primary institution seamlessly and at virtually no cost in response to dissatisfaction or promotional offers.

A large cohort of high share of wallet customers confers important advantages for the primary bank that can be exploited by introducing innovative financial products/services, enhancing customer service, upselling and cross-selling. That many of these same customers would retain a long and apparently satisfactory relationship with a second financial institution suggests that these advantages, while considerable, may not be insurmountable. For the primary financial institution, the true cost of a long and satisfactory secondary banking relationship could be far greater than what is implied by the short-term loss of some SOW to another financial institution.

\section{AUTHOR INFORMATION}

Raymond T. Kong is Senior Vice President with Ipsos Canada. As Global Financial Services Practice Leader, he coordinates consulting on customer experience, brand, operational improvement and strategy projects for financial services clients and leads an ethnic marketing practice that works with all types of companies to understand and respond to specific ethnic and cultural markets. An Adjunct Professor of Marketing at York University, Ray teaches Introductory and Advanced Marketing Research in the Bachelor of Administrative Studies program. He has published in Industrial Marketing Management and his work appears frequently at international conferences.

Manfred F. Maute is Professor of Marketing in the School of Administrative Studies, York University and holds a $\mathrm{PhD}$ in Marketing from the University of Tennessee and an MBA from the University of Manitoba. Dr. Maute has published more than 60 refereed articles on consumer post-purchase responses, service failure, relationship marketing and health care reform. His work appears in the Journal of Economic Psychology, Psychology \& Marketing, Applied Psychology, The International Journal of Knowledge, Culture and Change Management, and the Journal of Business Research among other journals, and he is a frequent contributor to national and international conferences.

\section{REFERENCES}

1. Anderson, E., Fornell, C. \& D. Lehmann (1994), Customer satisfaction, market share and profitability: Findings from Sweden, Journal of Marketing, 58(July), 53-66.

2. Anderson, E. \& Mittal, V. (2000), Strengthening the satisfaction-profit chain, Journal of Service Research, Vol. 3(2), 107-120.

3. Baumann, C., Burton, S. \& Elliott, G. (2005), Determinants of customer loyalty and share of wallet in retail banking, Journal of Financial Services Marketing, Vol. 9(3), 231-249.

4. Blattburg, R. \& Deighton, J. (1996), Manage marketing by the customer equity," Harvard Business Review, July-August, 136-144.

5. Bloemer, J., Ruyter, K. \& Peelers, P. (1998), Investigating drivers of bank loyalty: The complex relationship between image, service quality and satisfaction, International Journal of Bank Marketing, Vol. 16(7), 276-286.

6. Bolton, R. (1998), A dynamic model of the duration of the customer's relationship with a continuous service provider: The role of satisfaction, Marketing Science, 17(1), 45-65.

7. Colgate, M. (1999), Customer satisfaction and loyalty: How New Zealand banks need to improve," University of Auckland Business Review, Vol. 1(1), 36-48.

8. Cooil, B., Keingingham, T., Aksoy, L. \& Hsu, M. (2007), A longitudinal analysis of customer satisfaction and share of wallet: Investigating the moderating effects of customer characteristics," Journal of Marketing, Vol. 71(January), 67-83.

9. DeWulf, K., Oderkerken-Schroder, G \& Iacobucci, D. (2001), Investments in consumer relationships: A cross-country and cross-industry exploration, Journal of Marketing, Vol. 65(4), 33-50. 
10. Garland, R. (2004), Share of wallet's role in customer profitability, Journal of Financial Services Marketing, Vol. 8(3), 259-268.

11. (2002), Estimating customer defection in personal retail banking, International Journal of Bank Marketing, 29(7), pg. 317-324.

12. Hair, J., Black, W., Babin, B., Anderson, R. \& Tatham, R. (2006), Multivariate data analysis, Pearson Prentice Hall: Upper Saddle River NJ.

13. Hallowell, R. (1996), The relationships of customer satisfaction, customer loyalty, and profitability: An empirical study, International Journal of Service Industry Management, Vol. 7(4), 27-42.

14. Heskett, J., Sassser, Jr., E. \& Schlesinger, L. (1997), The service profit chain: How leading companies link profit and growth to loyalty, satisfaction and value. New York: Free Press.

15. Hogan, J., Lemon, K. \& Rust, R. (2002), Customer equity management: Charting new directions for the future of marketing," Journal of Service Research, Vol. 5(1), 4-13.

16. Homburg, C., Giering, A. \& Menon, A. (2003), Relationship characteristics as moderators of the satisfaction-loyalty link: Findings in a business-to-business context, Journal of Business-to-Business Marketing, Vol. 10(2), 35-62.

17. Jones, M., Reynolds, K., Mothersbaugh, D. \& Beatty, S. (2007), The positive and negative effects of switching costs on relational outcomes, Journal of Service Research, Vol. 9(4), 335-355.

18. Kalwani, M. \& Narayandas, N. (1995), Long-term manufacturer-supplier relationships: Do they pay off for supplier firms? Journal of Marketing, 59(January), 1-16.

19. Magi, A. (2003), Share of wallet in retailing: The effects of customer satisfaction, loyalty cards and shopper characteristics," Journal of Retailing, Vol. 79, 97-106.

20. Meyer-Waarden, L. (2007), "The effects of loyalty programs on customer lifetime duration and share of wallet," Journal of Retailing, Vol. 83(2), 223-236.

21. Mittal, V. \& Kamakura, W. (2001), Satisfaction, re-purchase intent, and re-purchase behavior: investigating the moderating effects of consumer characteristics, Journal of Marketing Research, 38(February), 131-42.

22. __ Katrichis, J., Forkin, F., \& Konkel, M. (1998), The asymmetric impact of negative and positive attribute-level performance on overall satisfaction and repurchase intentions," Journal of Marketing, 62(January), 33-47.

23. Oliver, R. (1999), Whence Customer Loyalty, Journal of Marketing, 63(July), 33-44.

24. Peppers, D. \& Rogers, M. (2004), Managing customer relationships: A strategic framework, John Wiley and Sons: Hoboken, NJ.

25. Perkins-Munn, T., Aksoy, L., Keiningham, T. \& Estrin, D. (2005), Actual purchase as a proxy for share of wallet, Journal of Service Research, Vol. 7(3), 245-256.

26. Reicheld, F. (1996), The loyalty effect: The hidden force behind growth, profits and lasting value, Harvard Business School Press: Boston.

27. Rust, R., Lemon, K. \& Zeithaml, V. (2004). Return on marketing: Using customer equity to focus marketing strategy, Journal of Marketing, 68(January), 109-127.

28. ___ Zahorik, A. \& Keiningham, T. (1995), Return on quality (ROQ): Making service quality financially accountable, Journal of Marketing, 59(April), 58-70.

29. Stewart, K. (1998), An exploration of customer exit in retail banking, International Journal of Bank Marketing, 16(1), 6-14.

30. Szymanski, D. \& Henard, D. (2001), Customer Satisfaction: A met-analysis of the empirical evidence, Journal of the Academy of Marketing Science, 29(Winter), 16-35.

31. Trubik, E. \& Smith, M. (2000), Developing a model of customer defection in the Australian banking industry, Managerial Auditing Journal, 15(5), 1-12.

32. Uncles, M., Dowling, G. \& Hammond, K. (2003), Customer loyalty and customer loyalty programs, Journal of Consumer Marketing, 20(4), 294-316.

33. Verhoef, P. (2003), Understanding the effect of customer relationship management efforts on customer retention and customer share development, Journal of Marketing, Vol. 67(4), 30-45.

34. Zeithaml, V. (2000), Service quality, profitability, and the economic worth of customers: What we know and what we need to learn, Journal of the Academy of Marketing Science, 28(10), 67-85.

35. _ L. Berry \& A. Parasuraman (1996), The behavioral consequences of service quality, Journal of Marketing, Vol. 60(2), 31-46. 